\title{
UNIVERSITYOF
}

FORWARD

THINKING

WESTMINSTER用

WestminsterResearch

http://www.westminster.ac.uk/westminsterresearch

Understanding Media Production: A rejoinder to Murdock and Golding

Dwyer, P.

This is an author's accepted manuscript of an article published in Media Culture and Society on 29 September 2016. The final definitive version is available online at: https://dx.doi.org/10.1177/0163443716671495

The WestminsterResearch online digital archive at the University of Westminster aims to make the research output of the University available to a wider audience. Copyright and Moral Rights remain with the authors and/or copyright owners.

Whilst further distribution of specific materials from within this archive is forbidden, you may freely distribute the URL of WestminsterResearch: ((http://westminsterresearch.wmin.ac.uk/)).

In case of abuse or copyright appearing without permission e-mail repository@westminster.ac.uk 


\section{Understanding Media Production: A Rejoinder to Murdock and Golding}

This article is a rejoinder to Murdock and Golding's response to my critique of the political economy of communications (PEC) analysis of media production (see Dwyer 2015). This article sets this exchange in the context of a broader debate in recent editions of Media, Culture \& Society (Garnham 2016, Fuchs, 2016) about the value of PEC. Much of the debate stems from Garnham's (2011) critical review of 40 years of PEC research.

Garnham's $(2011,2016)$ recent critique of the political economy of communications (PEC) has provoked a vigorous debate about the value of this approach. Garnham (2011) proposed that a satisfactory theory of cultural production would need to "go beyond" Marxist concepts of the labour process, exploitation, alienation, ownership and control. This produced a strenuous defence of this approach from those who (with Garnham, 1979) founded the discipline, both in the UK (Murdock and Golding, 1973, 2016) and the US (Meehan and Wasko, 2013). Recently, Fuchs (2016) has described Garnham's argument as both Thatcherite - in its "no alternative" acceptance of capitalism - and erroneous, because Marx's concepts can be successfully reinterpreted to analyse 'digital labour'

Murdock and Golding's (2016) response to my article (Dwyer, 2015) is part of their wider attempt to defend PEC against undermining from within (they describe Garnham as a "former political economy 'insider") and encroachment, from 'new' approaches, without. They suggest my critique of PEC misunderstands and "fundamentally misconstrues" its "central tenets" - (crucially, the relationships between structural, sectoral and workplace levels of analysis).

A response to their argument requires a very brief restatement. My article analysed attempts to explain changes in media production by using Marxist concepts to connect this workplace level with sectoral and structural levels. I addressed what I take to be the consensus of researchers in this tradition. This is the very widely repeated claim that media production, across a range of industries (including film, broadcasting, newspapers and games), has followed a general transition in the capitalist mode of production from mass production or Fordism, to flexible specialization or neo-Fordism (for references, see Dwyer, 2015). 
To subject this analysis to the best empirical test, I focused on Hollywood - by far the most well documented sector - and argued that the evidence does not remotely support the claim that film production was organized according to Fordist mass production principles -routinisation, deskilling and detailed division of labour. While the sector experienced fundamental change (the break up of the 'studio system') this did not reflect a structural 'crisis of Fordism', nor did film production in the workplace then undergo a transformation from routinisation to flexible specialization. Murdock and Golding call my analysis "a provocative rereading" of these studies of Hollywood, but they do not say they disagree with it.

My article concluded that, since Marxist concepts did not help explain these changes at the level of production, then, drawing on Garnham (2011), we need to "go beyond" these concepts to develop an alternative theory capable of articulating the 'relationships between media markets, project organization, creative management and specific media styles and genres' (Dwyer 2015 cited in Murdock and Golding, 2016:767). Murdock and Golding say they agree.

Thus, Murdock and Golding do not disagree with the detail of my argument, and actively agree with its conclusions for theory. However, they are strongly critical of my decision to focus on Hollywood and 'ignore' other relevant studies of production:

there is already a considerable body of research and conceptualisation that has this as its core aim and...critical political economy has made major contributions to realising it. (Murdock and Golding, 2016:)

They first attribute this neglect to ignorance - a charge I can refute. I was, like any passable media student, aware of these works, first citing them (when I read Garnham (1979) and Murdock and Golding's own (1973) pioneering work) almost 30 years ago (see Dwyer, 1989).

Secondly they suggest I "choose" to exclude these studies as part of an academic and political project to undermine PEC. They suggest I join a class of authors ("proponents of 'new' media industry and 'new' production studies" make "the same basic case") who are "erecting fences" between media production and PEC in order to provide "support for claims for the novelty and centrality of their work". Here Murdock and Golding echo Meehan and Wasko's (2013:49) defence of PEC against attempts by "emerging fields... to claim the study of media production in a palatable form for cultural analysts, policy wonks, and the 
media industry itself. In other words, an approach that isn't necessarily heavily invested in (overtly) neoliberal economics or media economics, nor one that has the taint of Marxism or political economy or a truly critical approach to media industries". Not Thatcherite, but close

In fact, my reasons for not discussing the works Murdock and Golding cite, were driven by a desire to provide a fair test of PEC's ability to explain production. First, I wanted to address the most detailed attempt to use Marxist concepts to explain cultural production- Hollywood. The works Murdock and Golding suggest I ignore deal primarily with UK TV production which, as they note, responds to TV's particular markets, regulation, technology and cultural forms (though Fordism/post-Fordism accounts of UK TV elide such sectoral differences).

Secondly, I did not consider production ethnographies, Weberian sociologies of media occupations and organizational accounts of 'the production of culture' to be typical of the PEC approach. Fuchs' (2016) defence of PEC via reinterpreted Marxist concepts suggests he would agree. But Murdock and Golding claim PEC incorporates these approaches. They argue: "critical political economy analysis has been able draw on the evidence generated" by these studies to try to rise to the "central challenge for theories of media production" which is "to move between levels of analysis and to integrate them."

Thus when I propose, as an alternative to PEC, an analysis of 'media production processes as responses both to common economic and organisational challenges and to media-specific creative and cultural influences' (Dwyer, 2015 cited in Murdock and Golding 2016:766) Murdock and Golding claim that this too constitutes PEC: "our approach to a political economy of communications has always advocated exactly this" (ibid).

This is the nub of the argument. I do have real difficulty in understanding how PEC integrates such diverse theoretical perspectives to explain the relationships between these levels of analysis. And, indeed the answer would seem to be that it doesn't or at least hasn't: "we are not arguing that the work we have cited offers a satisfactory solution to this challenge" (Murdock and Golding, 2016:768).

However, ultimately, Murdock and Golding and I are agreed on a number of key points. First, PEC does not offer a satisfactory solution to the challenge of explaining media production. Secondly, achieving such a solution requires a theory which draws on non-Marxist categories (they 
cite Weber's "market situation") to explain relationships between economic, sectoral and workplace levels. While they argue that PEC aims to do this (however unsuccessfully) I argue we require an alternative theory with greater clarity about the concepts to be used and how they are causally related. Murdock and Golding may call this PEC - others would not. But whatever it is called seems less important than the recognition that we need to get on and do it.

\section{References}

Dwyer, P. (1989) Community radio: professionalism, community access and technical Change (Unpublished $\mathrm{PhD}$, Imperial College)

Dwyer. P. (2015) Theorizing media production: the poverty of political economy. Media, Culture \& Society 37(7): 988-1004.

Fuchs, C. (2016) Against theoretical Thatcherism: a reply to Nicholas Garnham Media, Culture \& Society March 2016 38: 301-311,

Garnham N (1979) Contribution to a political economy of mass-communication. Media, Culture \& Society 1(2): 123-146. pp 343-367

Garnham, N. (2011) The political economy of communication revisited. In: Wasko J, Murdock G and Sousa H (eds) The Handbook of Political Economy of

Communications. New York and London: Wiley-Blackwell, pp. 41-61.

Garnham, N. (2016) Review of Fuchs, C. 'Digital Labour and Karl Marx' Media, Culture \& Society 2016, Vol. 38(2) 294-300

Murdock G and Golding P (2016) Political economy and media production: a reply to Dwyer in Media, Culture \& Society 2016, Vol. 38(5) 763- 769 Murdock G and Golding P (1973) For a political economy of mass communications. Socialist Register 10: 205-234.

Meehan, E. \& Wasko, J, (2013) In defence of a political economy of the media, Javnost - The Public, 20:1, 39-53, 